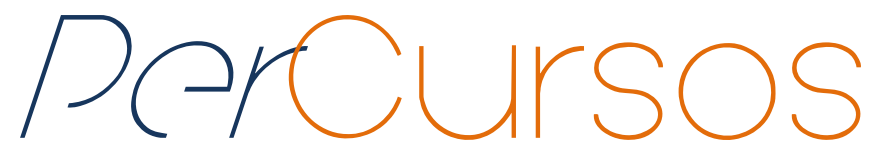

\title{
Post-disaster long-term recovery and reconstruction. Haiti after the earthquake in January 2010
}

\begin{abstract}
All over the world, natural hazards associated to climate change effects are increasing in frequency and threatening urban development dynamics while increasing human losses and economic expenditure. The objective of this paper is to investigate how post-disaster recovery and reconstruction should be addressed when associated with a scenario of urban poverty, lack of governance and social inequalities that can affect or restrict the capacity of a low-income country like Haiti to respond to natural hazards.
\end{abstract}

Letícia Tiemi Hirosue Corrêa Master in International Planning and Sustainable Development by the University of Westminster, London, United Kingdom.

Architect and Urbanist. Brazil

leticia.hirosue@gmail.com

Keywords: Disaster. Post-disaster. Recovery. Reconstruction. Haiti.

\section{To cite this article:}

CORRÊA, Letícia Tiemi Hirosue. Post-disaster long-term recovery and reconstruction. Haiti after the earthquake in January 2010. Revista PerCursos, Florianópolis, v. 18, n.36, p. 09 - 33, jan./abr. 2017. 


\title{
Recuperação e reconstrução pós-desastre a longo prazo. Haiti após o terremoto em janeiro de 2010
}

\begin{abstract}
Resumo
Em todo o mundo, os perigos naturais associados aos efeitos das mudanças climáticas estão aumentando em freqüência e ameaçando a dinâmica de desenvolvimento urbano, ao mesmo tempo em que crescem as perdas humanas e as despesas econômicas. O objetivo deste trabalho é investigar como a recuperação e a reconstrução pós-desastre devem ser abordadas quando associadas a um cenário de pobreza urbana, falta de governança e desigualdades sociais; as quais podem afetar ou restringir a capacidade de um país de baixa renda, como o Haiti, em responder aos perigos naturais.
\end{abstract}

Palavras-chave: Desastre. Pós-desastre. Recuperação. Reconstrução. Haiti. 


\section{Introduction}

The increase of extreme events and natural hazards happening in cities worldwide show evidence of climate change effects and how the dynamics of urban environment (transportation, infrastructure, communication) can be affected (SHELLER, 2013). Considering this scenario, this paper intends to analyse how post-disaster long-term recovery and reconstruction should be understood and addressed in a low-income country affected by an earthquake.

First, some definitions and an overview of the conceptual framework for postdisaster reconstruction will be presented as well as the main factors and issues to be considered. Followed by the analysis of a case study in Haiti and its reconstruction process. Finally, an evaluation of the lessons learned and conclusion.

\section{Conceptual Framework: definitions and rehabilitation in post-disaster} reconstruction and management

The common idea that disasters are difficult to predict and the destruction caused in urban areas are a mere consequence of extreme events normally result in restricted planning responses, mainly focused on physical aspects of a post-disaster context instead of including measures for risk reduction and preparedness. In fact, the relationship between cities and disasters is more complex than causes and effects, considering distinct features that need to be taken into account: physical space, built environment, politics and socio-economic characteristics (WAMSLER, 2014).

Normally, the post-disaster reconstruction responses comprehend three main stages:

- $\quad$ Early recovery: emergency or the immediate humanitarian relief that can occur for days, weeks or months.

- Transitional: addresses the recovery of economy and the main infrastructure as well as social institutions. It represents the period of transition to the longer-term when the reconstruction process can be started. 
- $\quad$ Medium-term and long-term recovery: reconstruction of a six-month period or many years.

\subsection{Definitions and disaster management}

According to Lloyd-Jones and Kalra (2010), the term disaster is defined as "the impact of different physical, social, economic, political and complex hazards on vulnerable communities" (p.10), which is focused on the same meaning applied to humanitarian practice.

Another definition for disaster describes it as "a serious disruption of the functioning of a community or a society causing widespread human, material, economic or environmental losses exceeding the ability of the affected community or society to cope using its own resources" (LLOYD-JONES, 2006, p.23). Other important terms related to the issue of post-disaster recovery and reconstruction are listed (based on the terminology of the United Nations International Strategy for Disaster Reduction UNISDR ${ }^{1}$ ) below:

- Natural disaster: it is related to disasters derived from geophysical and/or weather-related events.

- Hazards: could be environmental or man-made and they are linked with disasters when the vulnerability of population or infrastructure is affected.

- Disaster risk management: a systematic set of decisions and actions (policies, organisation, strategies and operational skills) to decrease the impact of natural disaster with the cooperation of civil society and communities.

- Disaster risk reduction: the development and implementation of strategic policies and practices to reduce vulnerabilities and disaster risks in a community.

\footnotetext{
1 United Nations International Strategy for Disaster Reduction (UNISDR), (2014). Terminology. Available from: < https://www.unisdr.org/we/inform/terminology> [Accessed 20 February 2014].
} 
- Mitigation: structural and non-structural measures used to constrain the multiple impacts of natural and technological hazards as well as environmental degradation.

- Vulnerability: a series of circumstances caused by social, economic and environmental factors that enhance the impacts of hazards in a community.

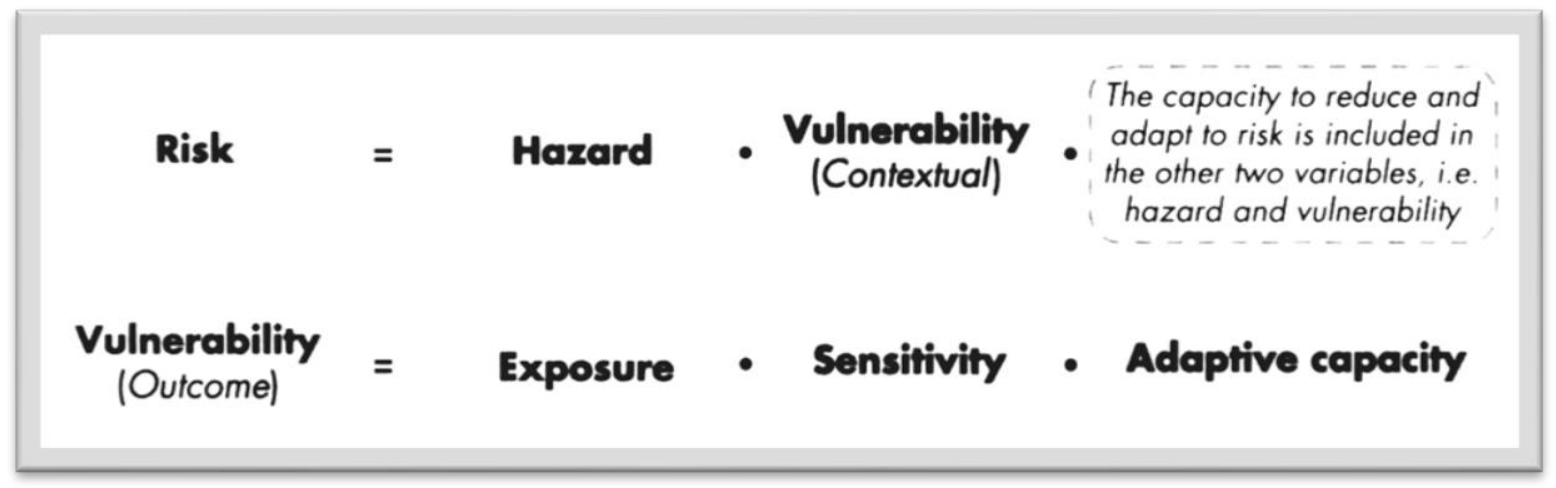

Figure 1 - Understanding contradictory concepts in disaster risk literature. Source: WAMSLER, 2014.

\subsection{Natural hazards and disasters affecting the urban environment}

Definitely, the low-income countries are the most exposed and affected by natural hazards. In fact, this is consequence of a scenario where the lack of governance and infrastructure, inappropriate investments, low professional expertise and corruption are present.

There is an estimation that climatic hazards are responsible for about two thirds of disasters, which shows an evidence of the connections between disaster risk and climate change (LLOYD-JONES, 2006). But this is also directly related to the urbanisation process, the growth of urban population living in risk areas and the expenditure and impacts of large-scale infrastructure, which increase risks and vulnerabilities.

The capacity to cope and respond to a disaster event is restricted in those places mostly due the absence of specialised medical emergency and other professional services (LLOYD-JONES, 2006). Consequently, this situation is worsened when taking into consideration the corruption, violence, armed conflict and governance issues in most of these nations affected by a scenario of poverty. 
Thus, the exposure to vulnerabilities become higher causing a disaster to result in loss of life, injury and damage to properties. On the other hand, developing countries with better governance tend to be more prepared for disasters and also increase the indices of human development (LLOYD-JONES, 2006).

\subsection{The gap between short-term and long-term recovery}

The failure of many responses and recovery processes from natural hazards relies not only on the absence of planning, risk management and targeted funding during the post-disaster rehabilitation stage. But also, the existing gap between humanitarian relief and long-term reconstruction represents a big issue that needs to be addressed in attempt to achieve an effective result in the whole process.

Normally, the focus is only on the immediate and basic needs (food, shelter, medical assistance) rather than include initiatives that will lead to a fast and efficient medium and long-term recovery and reconstruction. The early post-disaster relief tends to be very well conducted and adequate. On the other hand, the chances to use this stage to apply international good practice as a base for long-term reconstruction are frequently lost (LLOYD-JONES, 2006).

Thus, a wide range of reasons contribute to this loss like the political pressure for a short-term spending and early departure of international organisations involved; conflict of interests among distinct organisations and also between national and local governments. There is no agreement on how humanitarian action could assist long-term stages, even though exist a consensus related to the need for a connection between relief, reconstruction and development to build a recovery framework at early stage.

As known, humanitarian relief is based on actions coordinated mostly by UN agencies, NGOs, international agencies together with national instances like military force and civil defence; and supported by media interest (LLOYD-JONES, 2006). Opposite to that, national, sub-national and local governments conduct the long-term phase in a very limited way and very often need assistance of NGOs (both local and international). 


\subsubsection{Disaster risk reduction and planning development}

In recent decades, the international community made a significant progress in terms of increasing the knowledge and management of responses to natural disasters. This happened mainly through the implementation of disaster risk reduction policies and institutions, which have resulted in the creation of the Hyogo Framework for Action (HFA) during the World Disaster Reduction Conference in 2005 (LLOYD-JONES, 2006).

Briefly, the HFA was the first plan to define and detail priorities for action from all different sectors and actors to reduce disaster losses besides offering guidance on principles and practical means to achieve disaster resilience. However, the implementation of policies to reduce risks represents a major challenge, especially in developing countries. This is due the demand for specific approaches and mechanisms to guarantee appropriate management and funding of the reconstruction after unpredictable disasters.

In addition, there was an increase in the number of natural hazards associated to climate change while the application of disaster reduction policies and good practice by international agencies and governments are gradual and slow.

In areas predisposed to natural hazards (floods, earthquakes, volcanic eruptions), it is necessary to adopt a permanent disaster management including preventive actions and planning relief in attempt to reduce the impacts caused by such events. As known, this implementation is even more difficult in developing countries. In contradiction, in these places lie most of the risks and the inability to respond to disaster events.

Consequently, most of nations who lack organisation, preparedness and risk reduction besides public awareness (which are not prepared to meet and understand the issues and needs of communities) depend on military support to cope with natural disasters. 


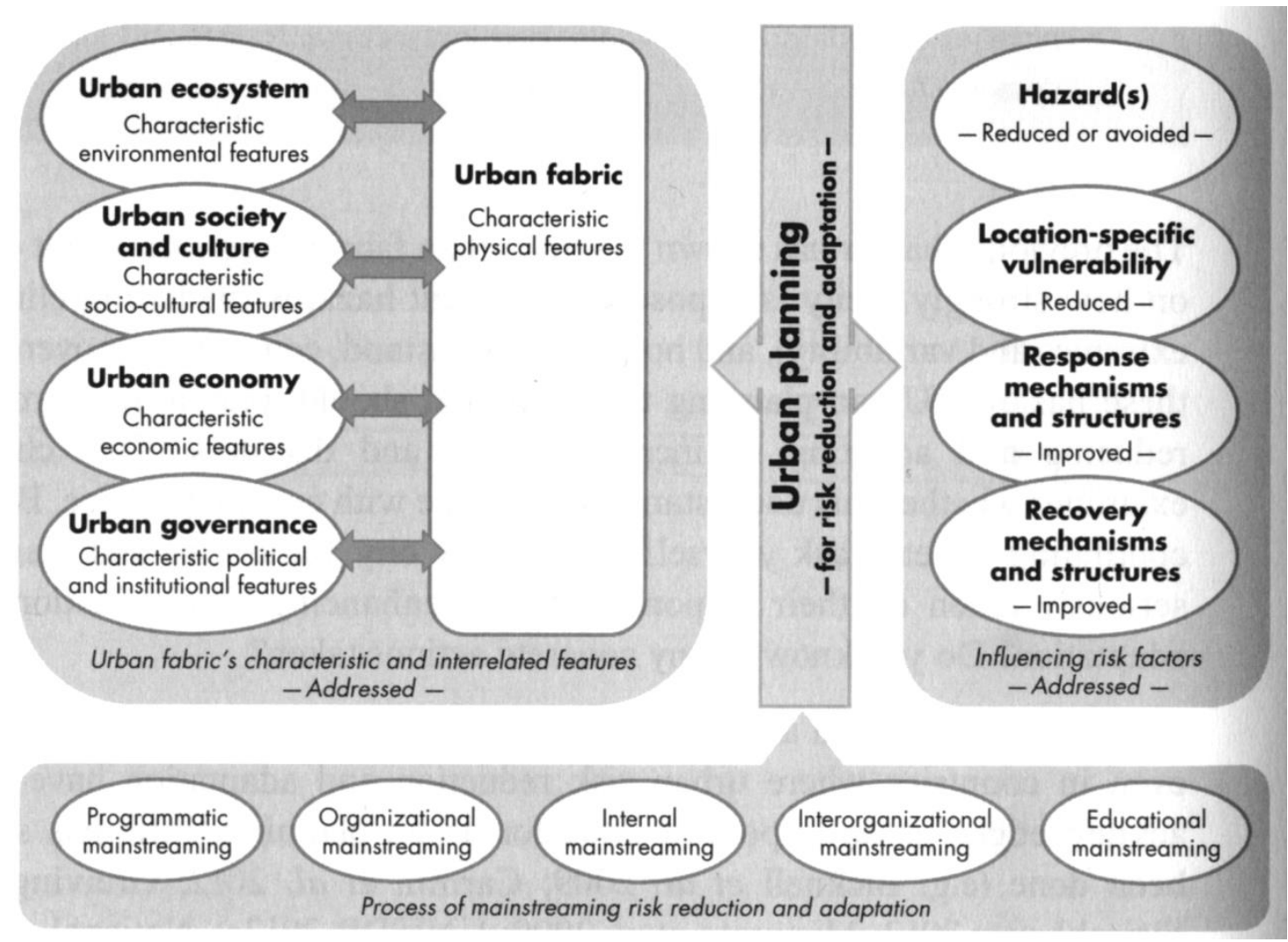

Figure 2 - Theoretical framework on how to achieve urban planning for risk reduction and adaptation. Source: WAMSLER, 2014.

Considering the inseparable linkage between relief, rehabilitation and development, there is an opportunity to implement the 'reconstruction-plus' (which means to develop and build better than it was before) during the disaster recovery process (LLOYD-JONES, 2006).

The recovery and reconstruction stage require a wide range of actions, initiatives and measures to be satisfactory and successful:

- $\quad$ Assessment of the disaster impacts at early stage;

- $\quad$ Cost planning and control (monitoring funding flows and expenditure);

- $\quad$ Clever use of technology (telecommunication, satellite images and GIS). 


\subsubsection{Decision-making and institutional constraints}

One of the main constraints during the process of recovery is the funding available and its distribution. It may affect and limit the improvement of early planning as well as the reconstruction management if not well allocated. Although succeeding in identifying and meeting local needs, the local grass roots, voluntary organisations and small NGOs are excluded from the long-term recovery programmes due to the premises that the government and other bigger agencies are more prepared to deal with the recovery challenge (LLOYD-JONES, 2006).

However, the result of this concentration of funding under the responsibility of government and major agencies is an overspending in emergency shelter instead of investments in transitional or permanent quality reconstruction. Consequently, it is observed an insufficient or a complete lack of finance and human resources for long-term recovery stages, especially because of wrong decision-making in terms of planning.

In this sense, a central planning and coordination to avoid concentrating funds and to better distribute is required, especially at local level. Also, there should be acceptance by international institutions of the existence and capacity of local organisations (which have better understanding of the community needs as they are in the front line of recovery actions). Thus, this could potentially diminish the gaps and provide access of these local agencies to targeted funding, professional skills and assistance.

\subsubsection{Community participation in the recovery process}

During the process of post-disaster recovery, it is extremely important that professionals involved create a good and strong relationship with local communities to better understand their needs and reality. Thus, recommendations for best practice suggest the employment of local professionals with enough knowledge of the affected area (LLOYD-JONES, T. ; KALRA, R., 2010).

However, sometimes it could be difficult to find skilled professionals in many lowincome developing countries. Then, the solution is making use of international experts in 
those cases. Other relevant aspect is to involve the community in disaster preparedness through training programmes in building maintenance and safety standards in construction.

In addition, the use of local expertise in construction is essential to avoid building unfamiliar forms or typologies with different materials and techniques. Thus, in attempt to reconstruct more resilient buildings and infrastructure, it is better to improve and adapt existing construction methods rather than use a 'quick fix' based on imported materials and methods that might be inadequate to the reality of the community (LLOYDJONES, T. ; KALRA, R., 2010).

Poor communities are the most affected by disaster not only instantly but especially during the prolonged process of reconstruction. In the recovery of disadvantaged communities, the role played by community-based organisations and local NGOs is essential because they can contribute to increase and restore both local and professional capacity.

\section{Haiti: the context before the disaster in 2010}

Haiti, located with other Caribbean islands, is characterized as a mobile region with migrants, refugees, tourists, money laundry and political instability. The idea of peacebuilding is totally discredited in Haiti due its past affected by violence, orthodox liberal approach in the 1990 s and limited stabilisation since 2004 (when the UN Security Council allowed military interventions). However, the scenario is characterized for French neo-colonialism, authoritarian government associated with dictatorship, social class inequality, poverty, racism and sexism (HORTON, 2012). 


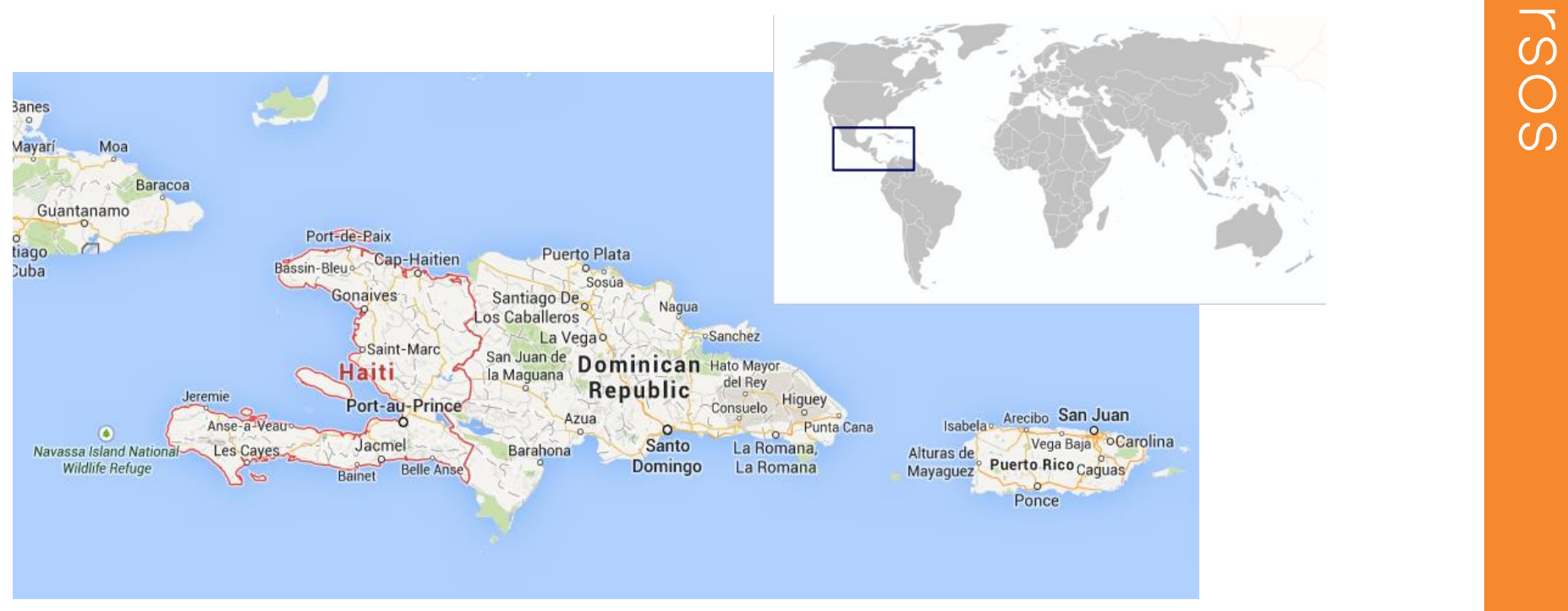

Figure 3- Map Location of Haiti. Source: GOOGLE IMAGES, 2014.

\subsection{Governance, Politics and Economy}

Haiti was founded in 1804 after a period of anti-colonial struggle. The nation is characterized by its single context. Since then, the country experienced constant international interventions (American occupation between 1915 to 1934) and also dictatorship periods like two of Duvalier from 1957 to 1986 (the Cold War era), which have deeper consequences in all sectors. In 1987, after Duvalier left the country, a constitution reinforcing democracy and social justice principles has been created.

In attempt to apply those principles, Jean Bertrand Aristide and the Lavalas party won the elections promoted in 1990. However, he has been exiled by the Armed Forces of Haiti in the following year and returned in 1994 after an intervention called Operation Restore Democracy (led by USA and sanctioned by UN).

Most of the international missions in Haiti were mainly for verification of elections and to guarantee governance mandates and human rights protection. On the other hand, there were international actions during mid-1980s with the objective to implement structural adjustment schemes (arranged between Haitian governments and donors). Back in 1994, President Aristide had implemented few economic reforms to remove subsides on goods and decreased tariff barriers aiming to protect the agricultural sector (BARANYI, 2012). 
Consequently, there had been an economic decline that resulted in governance crisis and violence in Haiti, which exposed the failures of liberal peacebuilding during the 1990s. The following government installed (President Préval) in 2004 was weak both in terms of political legitimacy and institutionally as the elections were contested. During this period, some social movements emerged and tried to secure laws, rights of women and agricultural procedures (BARANYI, 2012). In late 2008, floods and hurricanes harmed the already weak governance, infrastructure and urban fabric.

\subsection{Inequalities, vulnerabilities, gender and social issues}

The gender inequality in Haiti is a consequence and intensification of historical patterns of discrimination, specially related to women. Haitian women faced constant gender-based exclusion, violence and social inferiority status. This is also present in legal codes and policies. In general, the high levels of gender stratification in the country were linked with racial hierarchies and class inequalities that have given advantages to small lighter-skinned Haitians (HORTON, 2012).

The percentage of population living in poverty before the earthquake was $80 \%$ (according to UNDP, 2009). The factors that led to these conditions are: American military and economic interventions, lack of governance and constant instability in the global economy.

\section{The background and challenges after the earthquake in Haiti}

The earthquake occurred in January 2010 has caused an immense devastation and human losses (more than 200,000 were killed and one million people displaced) in Haiti. However, the response for humanitarian relief within days and the funding for reconstruction have been quick and generous, which reinforced Haitian's coping strategy and hope (BARANYI, 2012).

At that time, President Préval and Prime Minister Bellerive conducted the government. Both agreed and replicated the principle of 'build back better' as a post- 
disaster response to promote structural change, inclusiveness and long-term sustainability (as proposed by UN Special Envoy Bill Clinton and during the international conference mediated by major actors like the US and Canada). There were also the $A B C$ countries cooperation (Argentina, Brazil and Chile) with Haiti but it was modest in general due to different political interests and approaches adopted.

\section{TOTAL NUMBER OF DISPLACED INDIVIDUALS FROM JULY 2010 TO OCTOBER 2012}

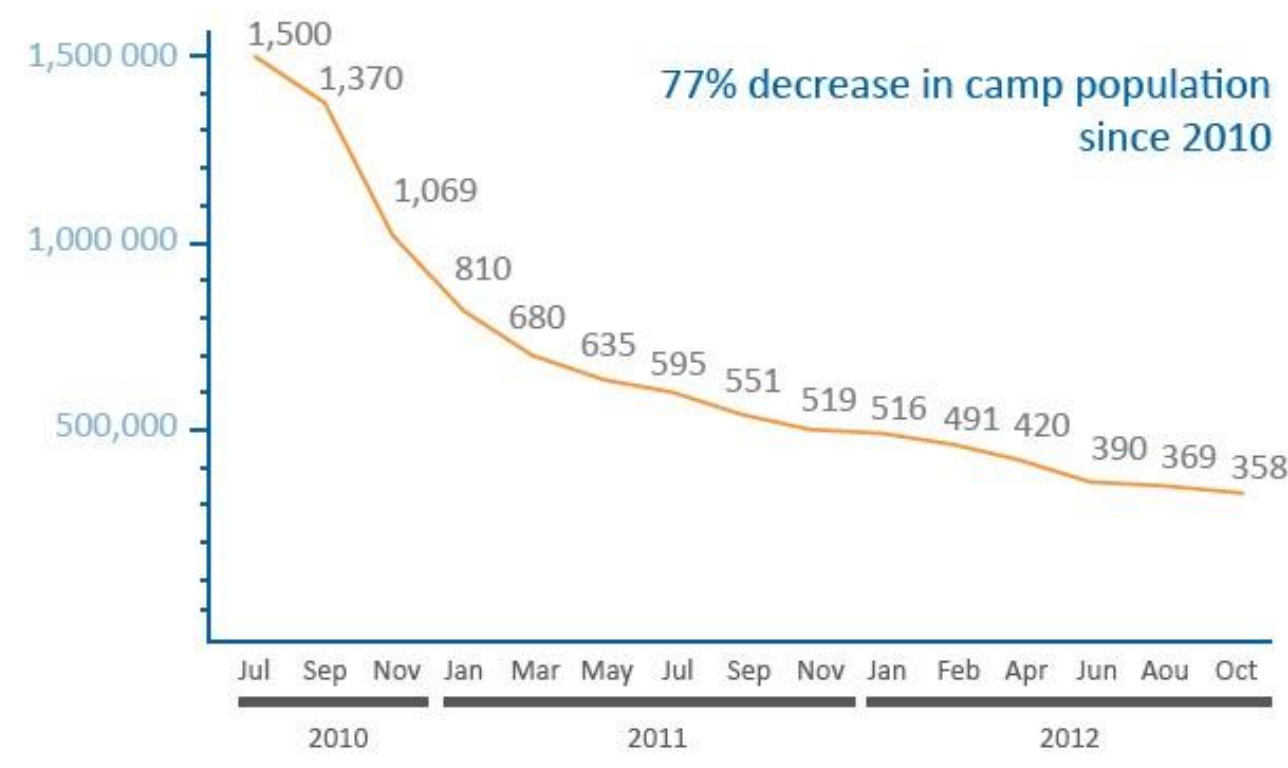

Figure 4 - Displaced Population in Haiti after the disaster. Source: UN REPORT - HAITI MOVING FORWARD 2012. 


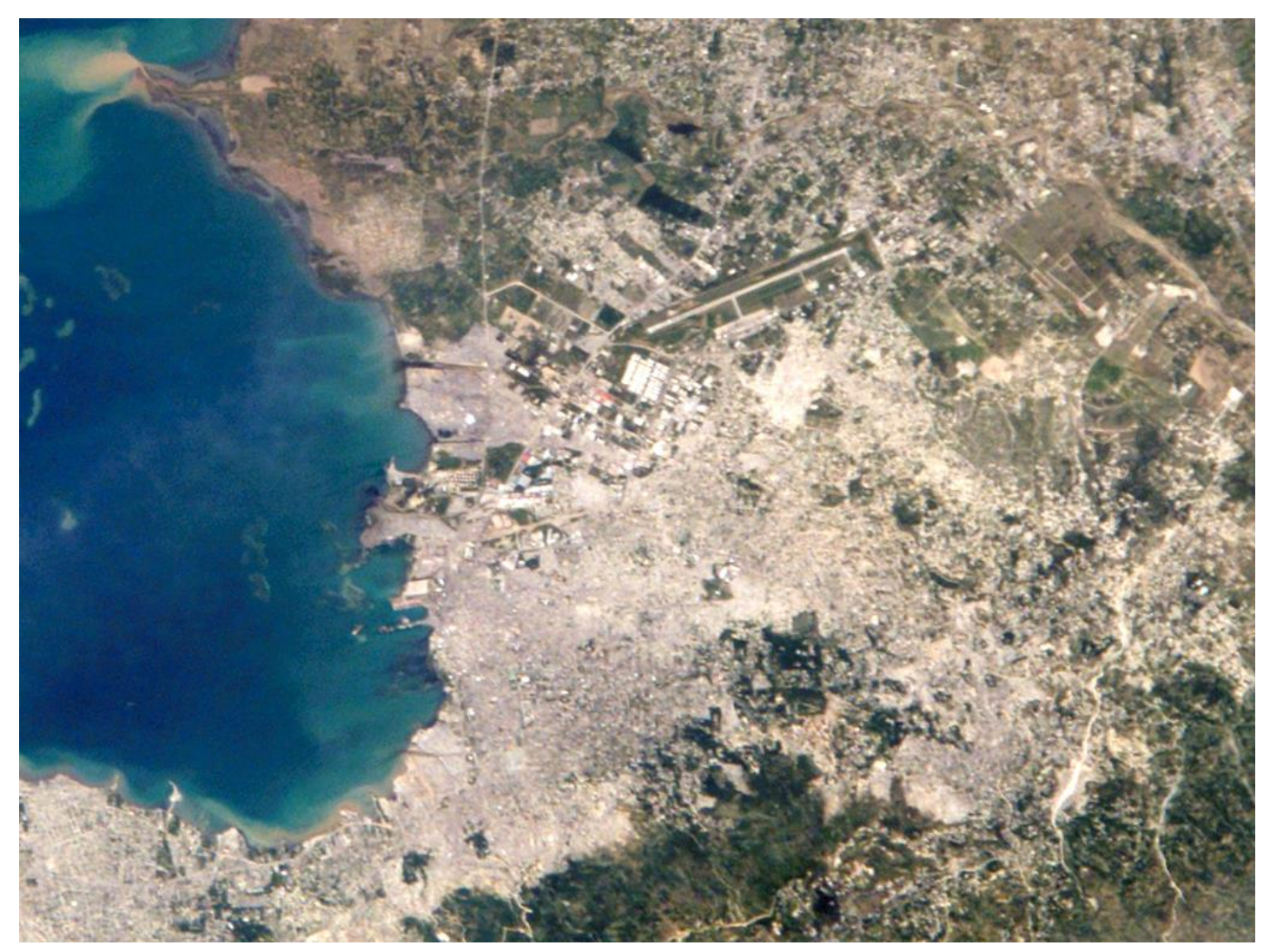

Figure 5 - Port-au-Prince after the earthquake in 2010. Source: NASA. 


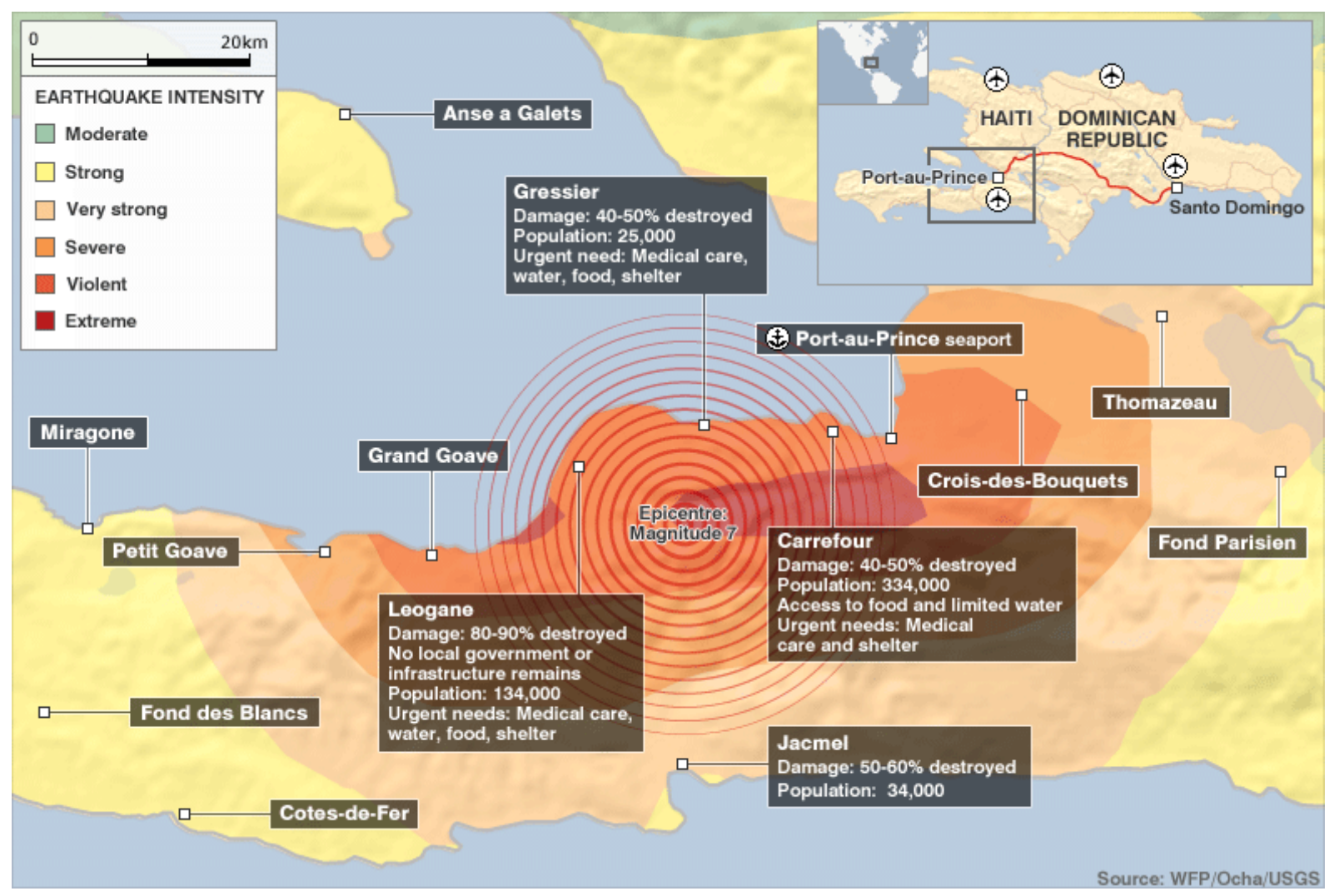

Figure 6 - Haiti's Earthquake Intensity and Cities Affected. Source: WFP/OCHA/USGS.

Disasters normally re-shape mobility systems and how they can be understood or associated to adaptation, climate change and vulnerability in small islands like Haiti (SHELLER, 2013). This will be analysed bellow.

\subsection{Evaluation of losses and damage estimation}

The post-earthquake in Haiti affected the mobility regimes (airport, docks, oil pipelines, internet connections and others), which caused loss of linkage between places and people (SHELLER, 2013). Consequently, the destruction of the capital Port-au-Prince resulted in millions of survivors displaced, flows of funds and disaster relief.

However, the majority of population was not allowed to leave the country not even for medical assistance, shelter or to stay with relatives. Problems like difficulty to access, failure to move citizens to temporary camps and removal of rubble arose making 
the situation even more chaotic. The urban spatiality of the capital formed by palatial houses on the hills, slums and a flood plan was completely destroyed.

During the humanitarian relief stage, groups of emergency responders, armed peace, and soldiers arrived in the affected site and took control of the main infrastructure (roads, airport, ports). After the earthquake, around 150,000 habitants left the country and more 500,000 moved from urban to rural areas in attempt to find shelter (SHELLER, 2013).

\subsection{Vulnerabilities, humanitarian and military interventions}

The Haitian sea and air space were controlled by the US military force (for humanitarian assistance) and also used as a way to prevent immigration of mass refugees off of the country. There was a sense of immobility or "islanding effect" due to the spatial isolation of population who could not move for medical care or obtain relaxation of migration controls to join the family (SHELLER, 2013).

Patterns of gender exclusion can be found at different levels in both relief and reconstruction periods. In the Haitian reality, this is related to meeting family survival needs, exploitation, racial and class stigmatisation and violence (HORTON, 2012). Another issue is the creation of stereotypes by the media, especially for those living in camps where men are defined as criminals and member of gangs. Woman are often stigmatised as prostitutes. Outside the camps, the poor black majority of Haiti is portrayed as disordered, violent and with social and cultural deficiencies. 


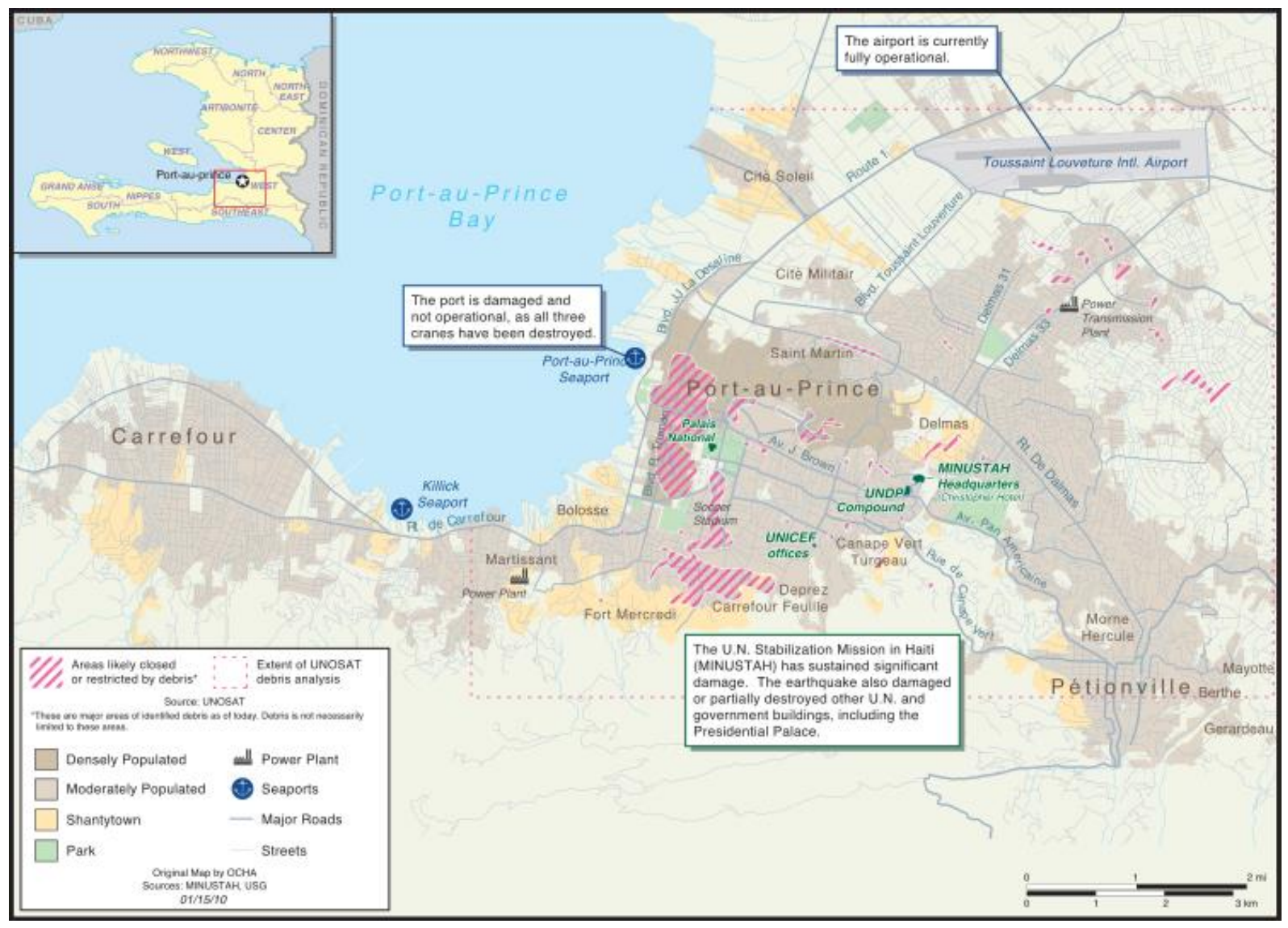

Figure 7 - Port-au-Prince with heavily damaged areas highlighted after the earthquake. Source: USAID - http://www.usaid.gov.

\section{Recovery process: the transition from humanitarian relief towards} reconstruction in Haiti

After the earthquake in Haiti and its terrible consequences, stakeholders were pessimist about the reconstruction along with the desire to built Haiti back better (BARANYI, 2012). Through the 2010 Action Plan for National Recovery and Development this intention of transformation by the government became clearer. However, since 2004, there were some influential actors and donors interested in achieving this like Chile, Argentina and Brazil through the United Nations Stabilisation Mission. Also, Venezuela emerged as the great bilateral donor in 2011.

This Action Plan highlighted the need to combine relief and reconstruction and to adopt long-term actions (over the first 18 months) to face the lack of development in 
Haiti and its main causes. There was no direct mention to peacebuilding or peace as goals in this plan, even though some of the priorities take into consideration the historic causes of violence. Included in the scope of immediate priorities, there was a 10-year plan to revitalise key economic sectors, decentralize territorial development, increase social services (health and education) and promote an efficient governance (BARANYI, 2012).

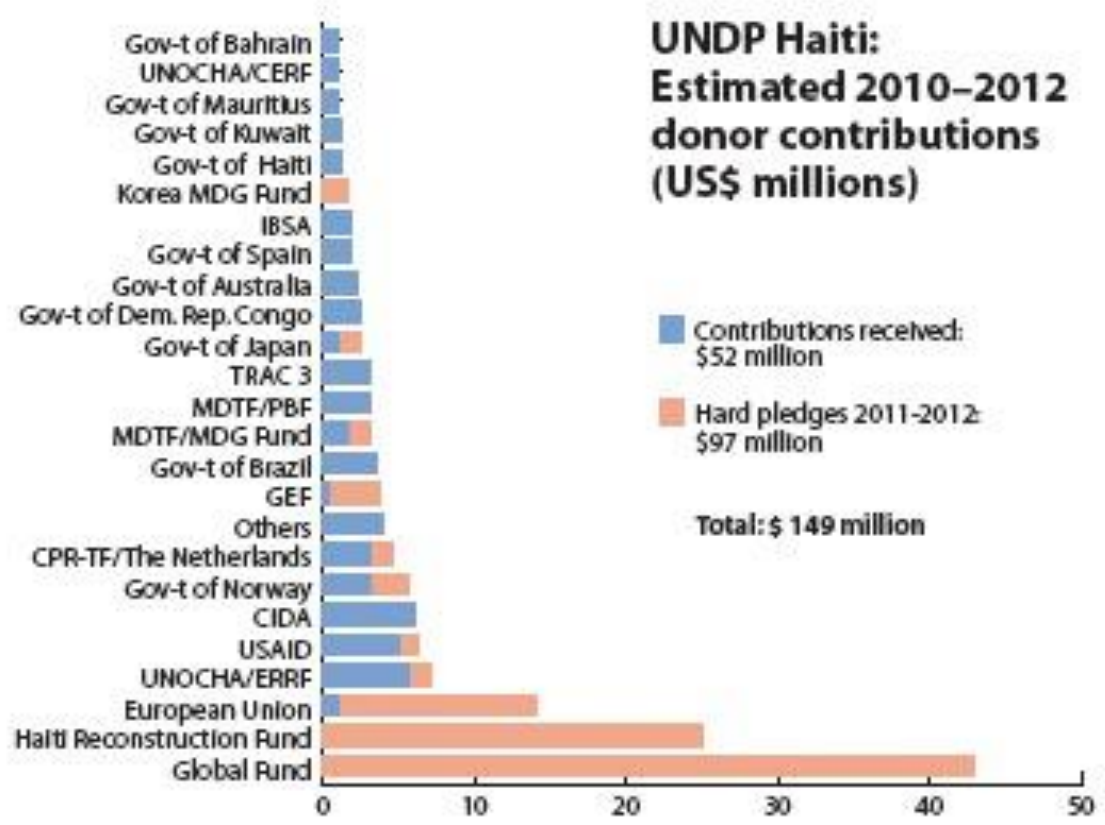

Figure 8 - Haiti's Donor contributions. Source: UN REPORT - HAITI 2011

In an attempt to better coordinate the efforts for relief and reconstruction, the Interim Haiti Recovery Commission (IHRC) was created. Also, considerable funding has been allocated in agriculture sector for subsistence and as a need to invest in areas outside the capital after the disaster. Nevertheless, little has been done until now.

\subsection{Challenges and constraints}

During the post-disaster relief stage, one of the challenges faced was the exclusion of women and no adequate responses to their needs in Haiti. Two main factors have contributed to it: international donor funding policies (that ignore citizen's 
capacities and needs) and women's well-being issues put under the responsibility of NGOs, which can be defined only by the state (HORTON, 2012). Also, the vast social and cultural experience of women organisations in Haiti had been ignored during the recovery phase.

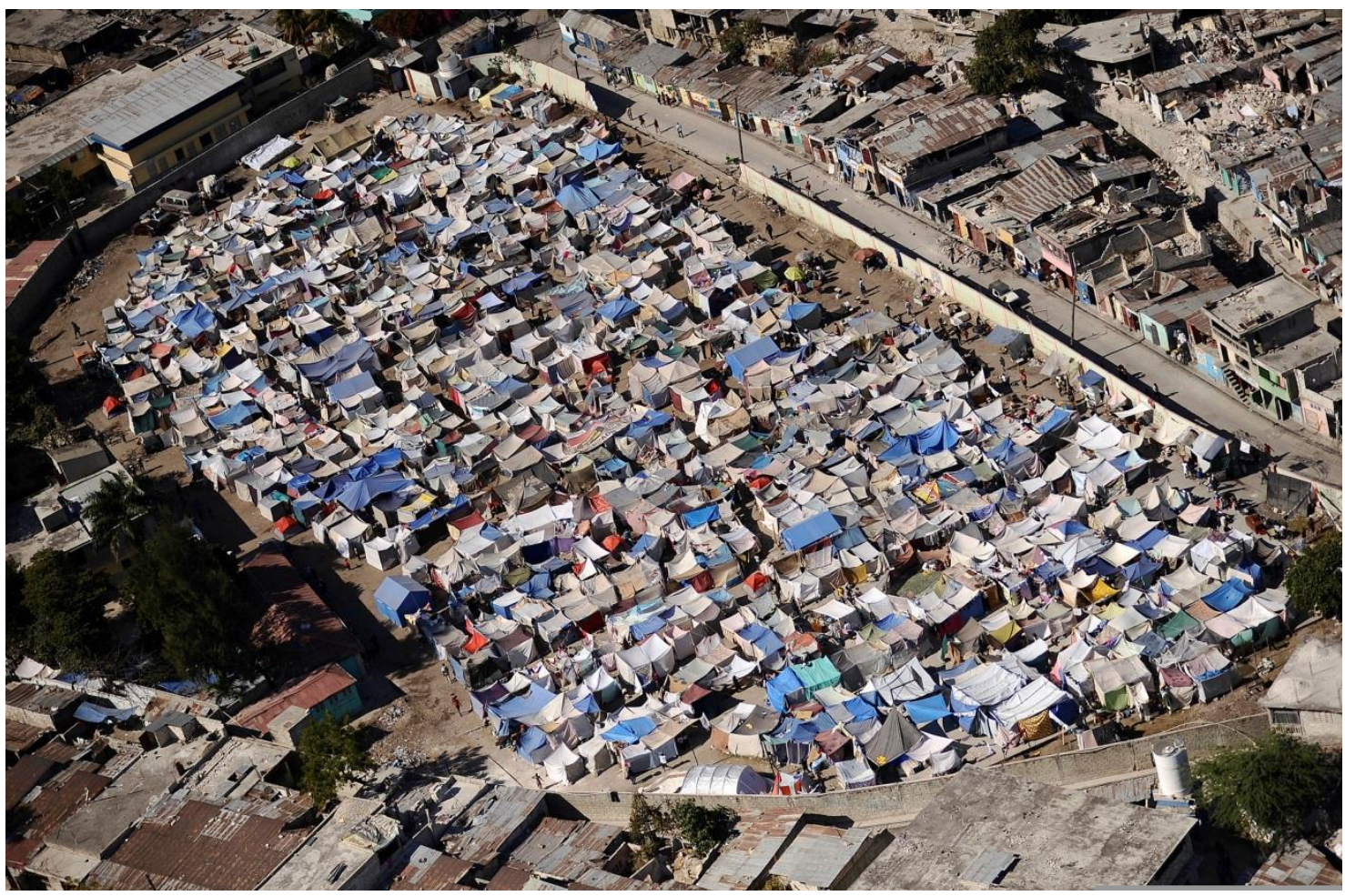

Figure 9 - Informal camps for displaced people in Haiti. Source: GOOGLE IMAGES.

Another issue is related to the failure in meeting women's needs in IDP camps during the relief and reconstruction processes. This state of class inequalities has also influenced the establishment of official and unofficial camps. The majority of people still living in the camps are poor women. When talking about the needs of the population, these means access to food, clean water, sanitation, health and appropriate housing. Educational and income-generating opportunities should be considered on the scope as well (HORTON, 2012). 


\subsection{Opportunities for change}

According to Horton (2012), disasters can offer an opportunity for the empowerment of women as the social and physical rupture caused by this event might affect the reproduction of gender. The experience in Haiti shown how gender inequalities still exist and may be intensified during disasters. Thus, the creation of post-disaster programmes for the implementation of a gender sensitive state and NGO policies can contribute to the empowerment and mobilisation of marginalised sectors of society. This will ensure that those people's needs will not be excluded.

\section{Lessons learned from Haiti}

\subsection{Achievements and experiences after the earthquake}

After the earthquake in 2010, the post-disaster reconstruction is still in progress and there is still a lot to be done. Most of Haitian citizens remain in a condition of permanent exclusion, vulnerability and insecurity. To overcome this situation is necessary a deep and real change of political, economic and social structures (BARANYI, 2012).

Even with some changes implemented, the major shifts needed were overshadowed by the efforts concentrated on stability and relief. The responsibility for this delay and marginalisation on the recovery process relies on the State and its historical impotence and incapacity to establish a partnership with the Haitians habitants. For example, the national elections after the disaster shown evidence of low participation of the citizens, which suggest changes in the social bases will probably remain weak in the next years.

\subsection{Organisation and Reconstruction Management}

Baranyi (2012) argues that the ideal of transformation in Haiti was lost two years after the disaster. This is a consequence of a lack of consensus, influence and interests between donors, government, NGOs and social movements during the definition of 
priorities and the implementation of reconstruction. Thus, the gaps between decisionmaking and implementation in long-term recovery have only increased.

In this sense, the alignment between Haitian's government and foreign actors would result in a bigger dependence of international funds and interventions. As a result, this situation could slow the implementation of reconstruction, increase the legislative paralysis and potentialise crisis of legitimacy and social explosions (BARANYI, 2012). Two years after the earthquake, the number of families that have been provided with permanent dwelling was only 25,000 of an overall estimated 1.5 million IDPs (HORTON, 2012).

\section{RECONSTRUCTION ACTIVITIES SINCE 2010 AND EXPECTED TRENDS IN 2013}

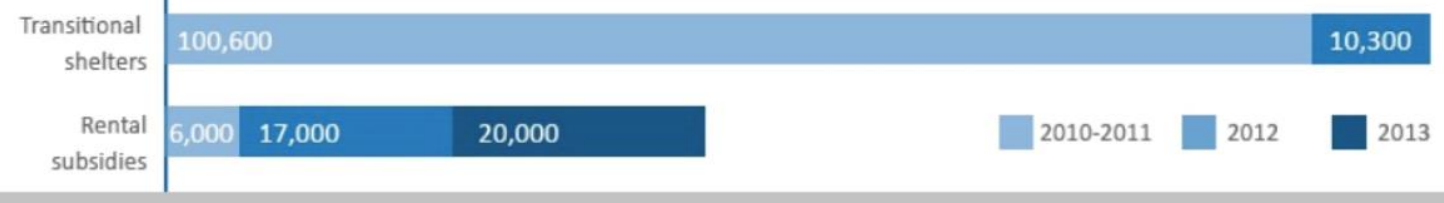

Figure 10 - Haiti's Reconstruction Activities. Source: UN REPORT - HAITI 2011.

\subsection{Gaps and fault lines in the processes}

Some experts argue that the major obstacles to reconstruction are related to the fragility of the Haitian government. As mentioned above, the country has a historic background of instabilities in governance. In addition, the massive destruction of public infrastructure caused by the earthquake prevented the state to lead the actions for relief and reconstruction (BARANYI, 2012). The fraud in the elections of November 2010 also contributed for the loss in credibility of the government by Haitians and the international community.

When talking about funds, it is known that more than half of the money and focus has been directed to short-term relief. After two years, the majority of reconstruction projects funded were used to restore or rebuild the government's institutions and the infrastructure. Not too much has been done in terms of political and institutional transformations. 


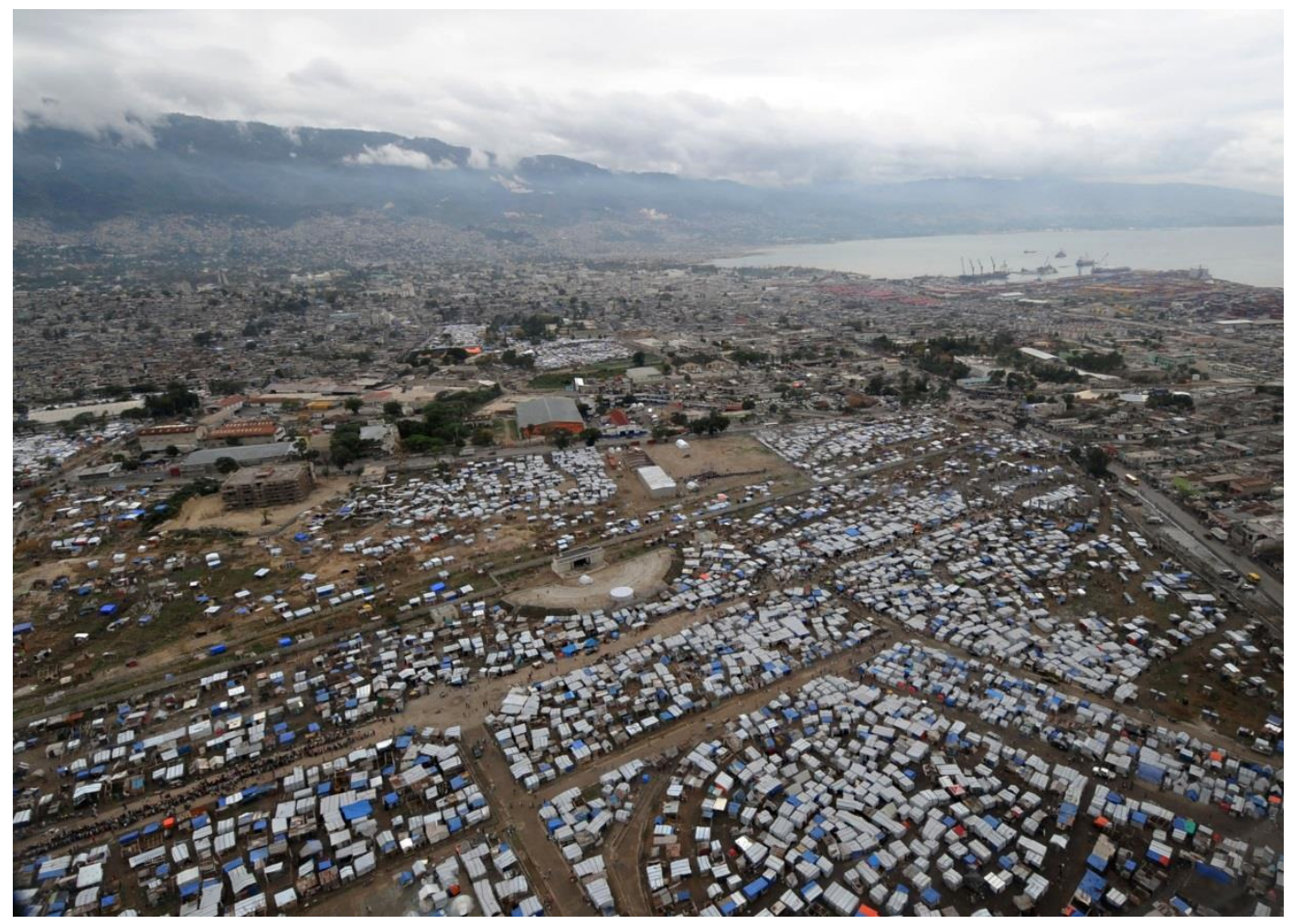

Figure 11 - Port-au-Prince: View of the remaining temporary shelter/camps after the disaster. Source: GOOGLE IMAGES.

Moreover, most of international NGOs fail to know the culture, history and social conditions of Haiti, which diminished the quality when applying gender programmes. Around one million people have left official camps and moved back to unsafe housing or unofficial camps (HORTON, 2012). The living conditions in the camps can be classified as inhuman due the absence of good sanitation and privacy.

\section{Conclusion}

In conclusion, the dramatic situation experienced in Haiti nowadays has been subject of discussions on how to adopt an inclusive development while finding a place in the actual stage of market-based globalisation. Disaster events tend to be painful and traumatic although it also offers the chance to start a shift in unequal gender regimes (HORTON, 2012). 
On the other hand, recovery and reconstruction decisions normally have long-term impacts on mobility and spatial inequalities. Even though Haitians citizens are expecting more participation during the reconstruction phase, the use of technologies and mobility control for monitoring and coordinate the post disaster recovery can generate the island effect, excluding and marginalizing the population (SHELLER, 2013).

As a result, the humanitarian actions have the responsibility to ensure mobility that will create movements of social inclusion to achieve post-disaster resilience. Prevention of future disasters should start at the community level and the reconstruction should improve traditional techniques and make use of local materials to decrease costs and be socially accept, not forgetting the community participation.

\section{References}

AUDEFROY, J.F. Haiti: post-earthquake lessons learned from traditional construction.

Environment and Urbanization. v.23, n.2 , p.447-462, 2011. Available at:

<http://eau.sagepub.com/content/23/2/447> Accessed: 06 February 2014.

BARANYI, S.Introduction: Peacebuilding and Reconstruction in Haiti. Journal of Peacebuilding \& Development. v.6, n.3, p.3-16, 2012. Available at:

<http://www.tandfonline.com/doi/abs/10.1080/15423166.2011.287073200651\#.UxXxg3mub pU>. Accessed: 20 February 2014.

HAITI. Government of the Republic. Haiti Earthquake PDNA: Assessment of Damage, Losses, General and Sectoral Needs. 2010. Available at:

<http://www.lessonsfromhaiti.org/report-center/>. Accessed: 20 February 2014.

HAITI. Government of the Republic. Action Plan for National Recovery and Development of Haiti. Immediate key initiatives for the future. 2010. Available at:

<http://www.lessonsfromhaiti.org/report-center/>. Accessed: 20 February 2014.

HORTON, L. After the earthquake: gender inequality and transformation in post-disaster Haiti. Gender \& Development. v.20, n.2, p.295-308, 2012. Available at:

<http://www.tandfonline.com/loi/cgde20 - .UxWZDHmubpU>. Accessed: 20 January 2014.

INTERIM HAITI RECOVERY COMMISSION. Haiti one year later: the progress to date and the path forward. 2011. Available at: <http://www.lessonsfromhaiti.org/report-

center/>.Accessed: 20 February 2014 
LLOYD-JONES, T. Mind the Gap! Post-disaster reconstruction and the transition from humanitarian relief. London: RICS, 2006. Available at: <http://www.preventionweb.net/files/9080_MindtheGapFullreport1.pdf>Accessed: 20 January 2014.

LLOYD-JONES, T. ; KALRA, R. The built environment professions in disaster risk reduction and response: RICS, ICE, RIBA, RTPI. London: MLC Press, 2010. Available at: <http://www.rtpi.org.uk/>. Accessed: 20 January 2014.

SHELLER, M. The islanding effect: post-disaster mobility systems and humanitarian logistics in Haiti. Cultural Geographies. v.20, n.2, p.185-204, 2013. Available at: <http://search.proquest.com/docview/1323498977?accountid=14987>. Accessed: 20 January 2014.

UNITED NATIONS . UN Fact Sheet: Haiti Moving Forward Step By Step 2012. 2012. Available at: <http://www.lessonsfromhaiti.org/report-center/> Accessed: 20 February 2014.

UNITED NATIONS DEVELOPMENT PROGRAMME (UNDP). Haiti One Year Later. 2010. Available at: <http://www.lessonsfromhaiti.org/report-center/> .Accessed: 20 February 2014.

UNITED NATIONS DEVELOPMENT PROGRAMME (UNDP) Haiti Rebuilds. 2011. Available at: <http://www.lessonsfromhaiti.org/report-center/>. Accessed: 20 February 2014.

UNITED NATIONS INTERNATIONAL STRATEGY FOR DISASTER REDUCTION (UNISDR). Terminology. 2014. Available at: < https://www.unisdr.org/we/inform/terminology>. Accessed: 20 February 2014.

WAMSLER, C. Cities, disaster risk and adaptation. London, New York: Routledge, 2014. 